\title{
浦安地区の地盤材料物性の把握と東北地方太平洋沖地震における $\mathrm{K}-\mathrm{NET}$ 浦安地震記録を用いた基盤上昇波の推定
}

\author{
金田一広 ${ }^{1 ）}$ 、中井健太郎 ${ }^{2)}$ 、野田利弘 ${ }^{3)}$ 、浅岡顕 ${ }^{4)}$ 、澤田義博 ${ }^{5)}$ \\ 1) 正会員 竹中工務店技術研究所、主任研究員 博(工) \\ e-mail : kaneda.kazuhiro@takenaka.co.jp \\ 2) 正会員 名古屋大学大学院工学研究科社会基盤工学専攻、准教授 博(工) \\ e-mail : nakai@civil.nagoya-u.ac.jp \\ 3) 正会員 名古屋大学減災連携研究センター、教授 博(工) \\ e-mail : noda@civil.nagoya-u.ac.jp \\ 4) 正会員（公財）地震予知総合研究振興会、工博 \\ e-mail : asaoka@8f.adep.or.jp \\ 5) 正会員（公財）地震予知総合研究振興会、理博 \\ e-mail : sawada@8f.adep.or.jp
}

要 約

東北地方太平洋沖地震では東京湾沿岸域の埋立て地盤で広範囲な液状化被害が発生した。 今後発生する巨大地震に対して液状化対策を行う上で、今回の地震被害について検証する 必要がある。このような地盤変状について再現シミュレーションをするためには地盤情報 と入力地震動の評価が重要であるとともに、複雑な現象を再現することのできる弾塑性有 限変形解析が必要である。本研究では土骨格構造の働きを記述できる弾塑性構成式(SYS Cam-clay model)を用いて、まず、浦安地区で詳細な地盤調查を実施し、地盤物性の把握と 共に弾塑性パラメータの同定を行った。次に、太平洋沖地震で観測された液状化の発生が みられず比較的非線形の影響が小さいと考えられるK-NET浦安の地表面加速度を取り上げ、 この構成式を搭載した有効応力解析コードGEOASIAを用いて、EW、NS両方向の観測波を 同時に再現するように基盤上昇波を伝達関数法によって推定した。

キーワード： 弾塑性、地震波の推定、地震応答解析

\section{1.はじめに}

東日本大震災において、浦安市をはじめとする東京湾沿岸部の埋立て地盤では広範な液状化の被害が 発生し、宅地やライフラインが甚大な被害を受けた。今後発生が危惧される首都直下地震や南海トラフ 巨大地震などに備えて、液状化危険個所を精緻に予測し、適切な対策を行うことが求められている。し かし、現行の液状化予測手法では不十分な点が数多く残されている。表1は、液状化対策技術検討会議 ${ }^{1}$ において、実際に関東地方で発生した液状化個所とFL法による液状化判定結果の比較を行った結果であ る。液状化しないと判定されていた地点が液状化したような、見逃しこそなかったものの、液状化と判 
定されていた地域で液状化しなかった地点が40\%ほどを占め、精度の高い予測とはなっていない。液状 化判定法の高度化のためにも有効応力解析によるシミュレーションが必要であることが述べられている。 今後液状化予測の精度を高は、実被害の再現シミュレーションを通して、その発生メカニズ ムを解明することが必要であると考えられる。精度の高い再現シミュレーションを行うためには、原位 置の地層構成や土の状態を正確に把握し、適切な入力地震動を用いることが重要である。

本論文では、東日本大震災における浦安市の液状化被害の再現と解明の基礎データとして、浦安地区 の正確な地盤材料物性の把握を1つ目の目的とする。そのために、実際に浦安地区でボーリング調查を行 い浦安地盤の地層構成や堆積状態を把握する。さらには、同地点から採取した不攪乱試料を用いて各種 室内試験を実施することで各地層の力学特性を把握するとともに、弾塑性構成式による力学挙動の再現 から、地震応答解析に必要なパラメータの同定を行う。2つ目の目的は、地震応答解析に用いるための適 切な入力地震動を推定することである。入力地震動に関しては、K-NETやKiK-netのような地表、地中観 測網が現在広く設置され、多くの強震記録がとられてきているが、これらの観測記録は、図1に示すよう に、上昇波と下降波が合わさった波(E+F波)である。地震応答解析では解析領域を設定し、入力する地盤 を仮想的な粘性境界上において上昇波(2E波)を入力して行うことがよくある。つまり、上昇波(2E波)を 外力として解析モデルに入力し、その結果として下降波( $\mathrm{F}$ 波)も合わさった加速度履歴(E+F波)がアウト プットされ、この履歴が観測波に対応する。すなわち、観測記録をそのまま粘性境界上に入力しても、 解析によってアウトプットされる波は観測波と一致しない。一方で、粘性境界ではなく加速度境界とし て観測記録を入力すれば、その位置での観測記録となるが、境界から下への逸散減衰を評価できず、あ たかも巨大な振動台で解析をしていることとなり現実的ではない。本研究ではSeedらが提案している観 測記録と地盤の伝達関数を使った方法を参考に 3 次元柱状モデルを用いて弾塑性構成式により上昇波 (2E波)を推定することを行う。

なお、地震応答解析においては、SHAKEやFLUSHといった解析コードが用いられることが多い。こ れら手法では地盤の密度やせん断波速度など、地盤のパラメータは比較的少ないが、対象が線形範囲内 に限定されるため、液状化現象のように大きな塑性変形を引き起こす現象まで説明することはできない。 また、地盤の非線形性を考慮したひずみ依存の構成式などもあるが、やはり液状化、あるいはその後の 沈下・変形まで説明できるモデルではない。さらに、浦安の地盤ではシルトなど細粒分が多い地盤であ り、このような土質材料の力学挙動を記述するモデルもない。しかし、本研究で用いる解析コードは砂 から中間土、粘土までを同じ理論的枠組で記述する弾塑性構成式、SYS Cam-clay model ${ }^{2}$ を搭載し、地震 中の不安定現象から地震後の変形挙動までを一貫して解くことのできる水〜土骨格連成有限変形解析コ ードGEOASIA ${ }^{3)}$ で検討している点が大きな特徵である。

\section{表1 PL法による液状化判定 ${ }^{1)}$}

\begin{tabular}{|c|c|c|c|c|}
\hline \multicolumn{2}{|c|}{} & \multicolumn{2}{|c|}{ Observed result } & \multirow{2}{*}{ Total } \\
\cline { 3 - 5 } & Liquefaction & $\begin{array}{c}\text { Non- } \\
\text { liquefaction }\end{array}$ & \\
\hline \multirow{2}{*}{$\begin{array}{c}\text { Forecast } \\
\text { result }\end{array}$} & $\begin{array}{c}\mathrm{F}_{\mathrm{L}} \leqq 1 \\
\text { Liquefaction }\end{array}$ & 53 & 35 & 88 \\
\cline { 2 - 5 } & $\begin{array}{c}\mathrm{F}_{\mathrm{L}}>1 \\
\text { Non-liquefaction }\end{array}$ & 0 & 24 & 24 \\
\hline \multicolumn{2}{|c|}{ Total } & 53 & 59 & 112 \\
\hline \multicolumn{2}{|c|}{} & \multicolumn{3}{|c|}{ (Unit: place) }
\end{tabular}

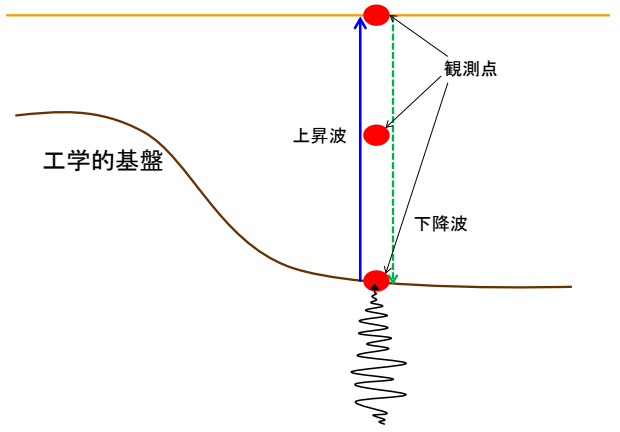

図1＼cjkstart地震動の伝達

\section{2. 浦安地盤の弾塑性材料定数の同定}

\section{1 浦安地盤の地層構成・材料特性の把握}

浦安地盤の地層構成および材料物性の把握のために、図 2 に示す A 地点と B 地点でボーリング調査お よび不攪乱試料の採取を行った。A、B 両地点とも東北地方太平沖地震では液状化が発生していない。A 地点は従来からの陸域であり、B 地点は埋立地に相当する。粘性土はシンウォールサンプリングにより 
試料を採取し、砂質土はトリプルチューブサンプリングにより試料を採取した後すぐに凍結させ、その まま成形した後、三軸セル内で解凍して室内実験を行っている。図 3 と図 4 に A、B 両地点で実施した ボーリング調査（標準貫入試験および PS 検層）の結果を示す。浦安地盤は大別して、表層から埋立土

(BF 層)、沖積砂（As 層）、沖積粘土（Ac 層）と堆積しており、その下に比較的硬質な洪積層が堆積し ていることがわかる。沖積砂の層厚は両地点ともに $10 \mathrm{~m}$ 程度と等しいが、沖積粘土の層厚は、陸側の $\mathrm{A}$ 地点では $10 \mathrm{~m}$ と薄いのに対して、海側の B 地点では $50 \mathrm{~m}$ と厚くなっており、総じて基盤面が陸側から 海側へ傾斜していることがわかる。図 5 に粒径加積曲線を表 2 と表 3 にそれぞれ A 地点と B 地点の採取 試料を用いて実施した物理試験のまとめを示す。表中の $\rho_{s} 、 w_{\mathrm{L}} 、 w_{p} 、 I_{p} 、 \mathrm{e}_{\max } 、 \mathrm{e}_{\min }$ はそれぞれ、土粒子 密度、液性限界、塑性限界、塑性指数、最大間隙比、および最少間隙比を示す。BF 層と As 層は各層の 中央部で、層厚の厚い Ac 層は堆積状態を把握するために複数地点で寒施している。各試料の特徵を簡 潔に示すと、以下の通りである。埋立土は、工学的分類では【粘土質砂：SC】に分類される。細粒分 含有率は約 $45 \%$ と多く、粘土分がその内の $20 \%$ 程度を占める。材料的には液状化しにくい土と判断され るが、東日本大震災では噴砂試料の調查から細粒分を多く含む土が液状化したことが報告されている ${ }^{4)}$ 。

物理特性は B 地点の 1 深度でしか実施していないが、埋立土は同じサンプラーでも場所によって状態 や種類のばらつきが大きい。沖積砂は、工学的分類では、【シルト混じり砂：S-M】に分類される。細 粒分含有率は $14 \%$ 程度と比較的少なく、材料的には液状化しや寸い土と判断される。採取箇所での N 值 は最大で 20 と液状化判定の対象となってくる。A、B 両地点で物理試験を実施したが物理特性はよく 似ており、同一層内であれば採取場所が異なっても同じ材料であると見なすことができる。沖積粘土は、 工学的分類では、【粘土（高液性限界）：CH】に分類される。採取深度によって異なるが、細粒分含有 率は 60～100\%（粘土分含有率は 30～50\%程度）と大きい。端部を除いて N 值が 0 2 程度と小さい。浅 部の Ac1、Ac2 に不純物は少なかったが、深部の Ac3 は有機物や貝殼の混入率が高く、液性限界・塑性 限界も上部と比べて小さいため、異なる粘性土として扱う必要があると考えられる。

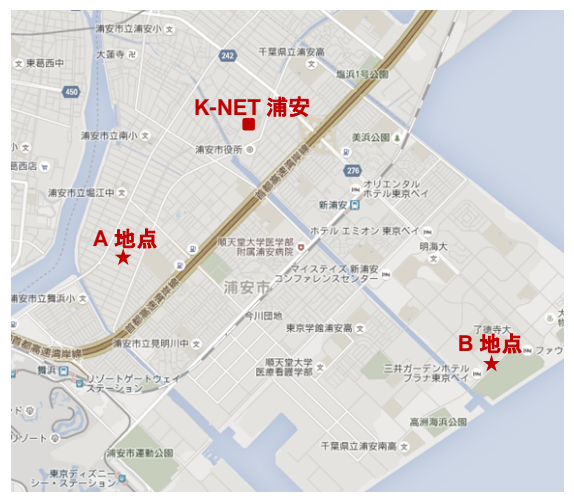

図 2 浦安地区とサンプリング地点 (Google Map を修正·加筆)

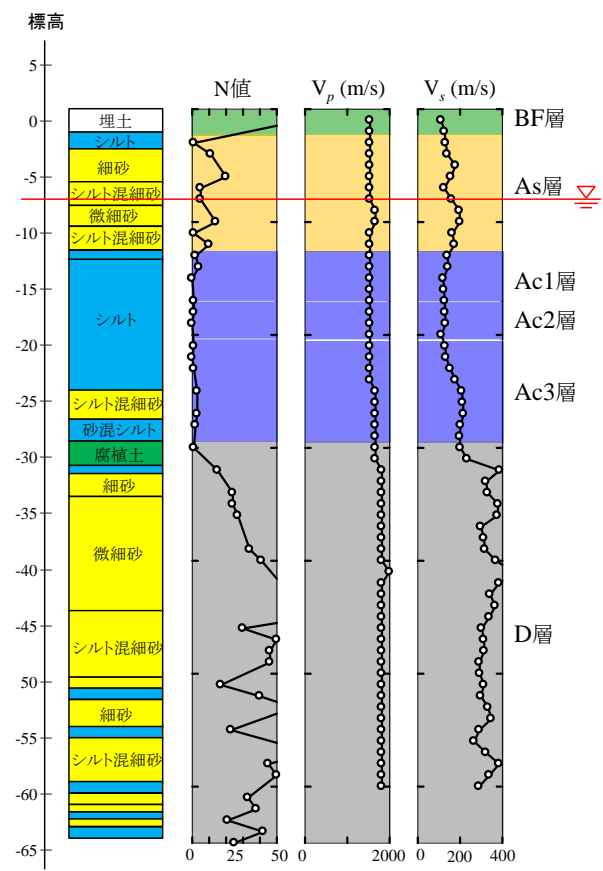

図 3 A 地点のボーリング結果 


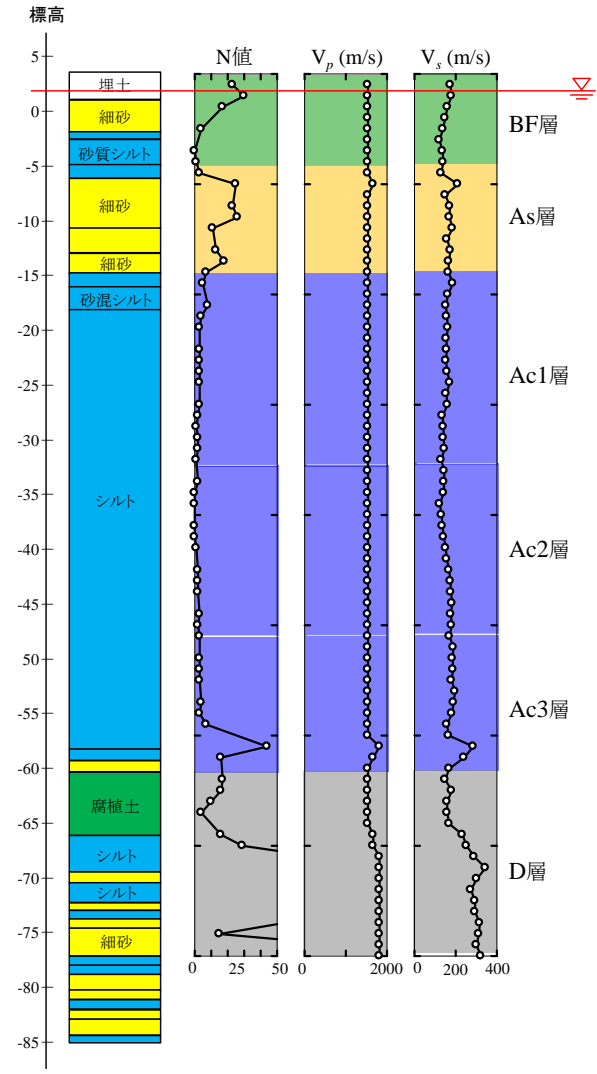

図 4 B 地点のボーリング結果

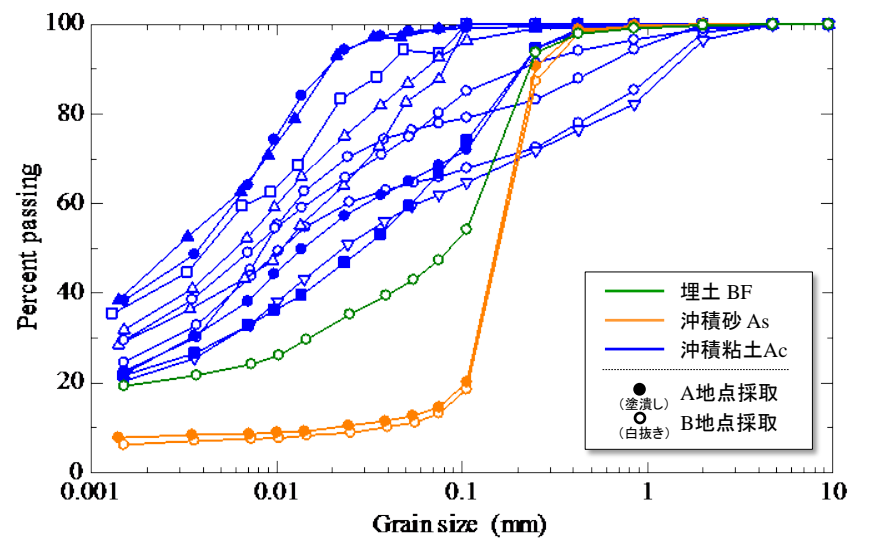

図 5 粒径加積曲線

表 3 B 地点の物理特性

表 2 A 地点の物理特性

\begin{tabular}{|c||c|c|c|c|c|c|}
\hline 深度 $(\mathrm{m})$ & $\rho_{\mathrm{s}}$ & $w_{\mathrm{L}}$ & $w_{p}$ & $I_{p}$ & $\mathrm{e}_{\max }$ & $\mathrm{e}_{\min }$ \\
\hline \hline $9.0 \sim 9.9$ & 2.783 & - & - & - & 1.350 & 0.832 \\
\hline $16.4 \sim 17.3$ & 2.670 & 100.8 & 39.9 & 60.9 & - & - \\
\hline $20.0 \sim 20.8$ & 2.689 & 106.6 & 53.9 & 52.7 & - & - \\
\hline $24.0 \sim 24.8$ & 2.697 & 89.2 & 35.3 & 53.9 & - & - \\
\hline $26.0 \sim 27.0$ & 2.740 & $\mathrm{NP}$ & $\mathrm{NP}$ & $\mathrm{NP}$ & - & - \\
\hline $28.5 \sim 29.3$ & 2.754 & 44.4 & 21.2 & 23.2 & - & - \\
\hline $31.0 \sim 31.9$ & 2.731 & 58.2 & 23.9 & 34.3 & - & - \\
\hline
\end{tabular}

\begin{tabular}{|c||c|c|c|c|c|c|}
\hline 深度 $(\mathrm{m})$ & $\rho_{\mathrm{s}}$ & $w_{\mathrm{L}}$ & $w_{p}$ & $I_{p}$ & $\mathrm{e}_{\max }$ & $\mathrm{e}_{\min }$ \\
\hline \hline $5.0 \sim 5.9$ & 2.677 & 35.4 & 23.2 & 12.2 & 1.637 & 0.903 \\
\hline $14.0 \sim 14.9$ & 2.787 & - & - & - & 1.388 & 0.844 \\
\hline $24.0 \sim 24.9$ & 2.690 & 95.2 & 40.8 & 54.4 & - & - \\
\hline $28.0 \sim 28.9$ & 2.695 & 124.1 & 49.3 & 74.8 & - & - \\
\hline $32.0 \sim 32.8$ & 2.686 & 74.1 & 45.8 & 28.3 & - & - \\
\hline $40.0 \sim 40.8$ & 2.753 & 85.9 & 53.9 & 32.0 & - & - \\
\hline $44.0 \sim 44.9$ & 2.731 & 72.9 & 40.4 & 32.5 & - & - \\
\hline $48.0 \sim 48.9$ & 2.770 & 73.6 & 30.6 & 43.0 & - & - \\
\hline $52.0 \sim 52.9$ & 2.708 & 56.1 & 33.4 & 22.7 & - & - \\
\hline
\end{tabular}

\section{2 浦安地盤の弾塑性性状の決定}

本節では、不攪乱試料を用いた力学試験結果を土骨格の弾塑性構成式SYS Cam-clay modelで再現する ことによって、地震応答解析に用いるパラメータの同定を行う。本解析で用いているこの構成式につい て簡単に説明をする。自然に堆積した土は人工的に作製した土とは異なり、年代効果やボンディングな ぞの作用によって構造·過圧密・異方性などいわゆる「骨格構造」が発達しているといわれている。そこ で、SYS Cam-clay modelは練返し正規圧密土の力学挙動を表すCam-clay modelを土台にして、土粒子が構 成する骨格構造の概念とその働きを塑性変形と関連づける発展則を導入して構築している。この構成式 に従うと、粘土と砂の差異は単位塑性変形あたりの骨格構造の変化のしや寸さ（骨格構造の発展則）で 表すことができ、粘土から砂までを連続的に取り扱うことができるのが特徽である。この構成式は、典 型的な粘土は、単位塑性変形あたりに生じる構造の劣化や異方性の発展の程度は小さく、過圧密の解消 の程度は大きくなるとして、一方、典型的な砂は、単位塑性変形あたりに生じる構造の劣化や異方性の 
発展の程度は大きく、過圧密の解消の程度は小さくなるとして、記述することができる。このことから 構造・過圧密・異方性の発展則の大小によって、典型的な粘土から砂の間に稠密に存在する中間土の力 学挙動も再現することが可能である。

土の弾塑性パラメータを特定するためには、まず、骨格構造の影響ができるだけ現れない状態（例え ば、練返しの状態）を室内試験機で再現する必要がある。次に発展則パラメータを特定するためには、 骨格構造が発達した試料の複数の試験結果を一組の材料定数群で再現できるように、骨格構造の初期値 とともに試行錯誤的に求める。しかし、いくら室内試験結果を再現して室内試験開始時の状態を把握す ることができても、サンプリングする前の地盤堆積時の状態を知ることはできない。つまり、サンプリ ングから試験機セット時までの乱れによって土の状態量が変化してしまうためである。ここでは「室内 試験はサンプリング時から始まっている」という考え方に基づき、室内試験結果の再現とともに地盤の 初期值を決める1つの方法を示す。つまり、室内試験結果の再現の際は、図6で示寸ように、現地盤での 堆積時の状態を初期状態に取り、採取土の土被り圧と土の骨格構造の初期状態を仮定して、エレメント 性が保持されるようなサンプリングー試験機セット 試験までの理想的な一連の過程を再現しつつ、各 種力学試験結果を満足するように試行錯誤的に決定する5)。このように力学試験開始前に生じるサンプ リング後の供試体設置による土の乱れの影響までも考慮して力学挙動の再現を行うので、逆解析的に、 堆積時の地盤の初期状態を推定することが可能となる。

図7〜図9に図2中のA地点およびB地点で採取した浦安市地盤の埋立土、沖積砂、沖積粘土のせん断試 験結果の再現結果を示す。図7の埋立土の圧密圧力は、 $\mathrm{K} 0=0.6$ 仮定した土被り圧相当の $40 \mathrm{kPa}$ で実施し、

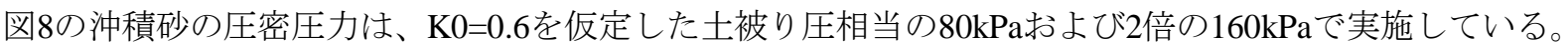

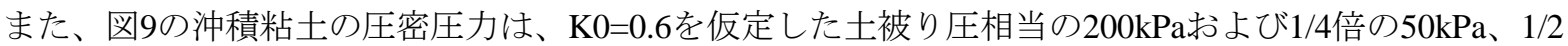
倍の $100 \mathrm{kPa} 、 2$ 倍の $400 \mathrm{kPa}$ で実施している。物理特性の比較結果から、採取場所が異なっても同じ土層 であれば同じ材料であると考えている。プロットは実駼結果を、実線はSYS Cam-clay modelによる再現 結果である。埋立土の排水せん断挙動（図7）は、体積収縮（負のダイレイタンシー）が見られ、密な状 態ではなかったことがうかがえる。沖積砂の排水せん断挙動（図8）は、体積膨張（正のダイレイタンシ 一）が見られ、やや密な状態にあったと言える。沖積粘土の非排水せん断挙動（図9）は、ひずみ軟化挙 動を示しており、構造高位で鋭敏な粘性土の特徵を示している。実験結果と再現結果を比較すると、い ずれの試験結果もよい対応が取れている。なお、Ac層については深度によって物理特性が異なっていた ため、粘土層を上・中・下の3つに分割し、それぞれAc1、Ac2、Ac3として深度による状態の違いを標 準圧密試験結果からさらに詳しく推定した。図10〜図12にA、B両地点から採取した不攪乱試料および練 返し試料の標準圧密試験結果を示す。Ac1とAc2を比較すると、練返しの圧縮線は等しく同じ材料として 扱えることがわかる。Ac2は初期比体積が大きく、練返し圧縮線の外側に嵩張っている状態にあり、鋭 敏な粘性土であることがわかる。一方、Ac1は圧密降伏応力を迎えた後は練返しの圧縮線とほぼ一致し 高張った状態にはない。一方、Ac3を見てみると、練返しの圧縮線の勾配がAc1、Ac2と比べて小さく、 初期比体積も小さい。Ac3はAc1、Ac2と比べて圧縮性の小さい粘性土だと考えることができる。Ac3は 試料抜出時にも有機質が多く含まれていたためと考えられる。続いて、A地点とB地点で比較してみると、 相対的に同じ位置から採取した試料同士の圧縮挙動はよく似ている。以上から、沖積粘土Ac層は物性お よび状態の異なる3層に分割することができ、相対的に同じ深さにある場合は同じ状態量にあると推定で きる。再現から得られた各土材料の材料定数と堆積時の初期状態を表4に示す。

図13にはA、B両地点の鈆直方向の一次元モデルを示す。同図には観測結果および上記表4の弾塑性定 数から算出されるVsが併記してあるが、おおむ社両地点ともに適切なモデル化が行われていると考えて いる。例えばB地点の埋立土層（BF層）においては埋土、細砂、砂質シルトの3種類から成っているが、 本解析では1つの材料定数群として取り扱った。埋立年代によって埋め立てられる材料が異なっているた め全体的に埋立層は不均質な材料と考えられる。今回サンプリングして得られた材料を埋立層の代表値 として取り扱った。さらに、若干の差異があるものの、本検討では場所が異なった場合でも同じ土層で あれば同じ弾塑性パラメータであるという仮定のもと検討を行っている。ボーリング調查の結果でも述 べたが、埋立土層は場所によって状態や種類のばらつきが大きいため、実測值とのかい離がみられたと 考えられる。 


\section{原位置〜室内試䄼の再現}

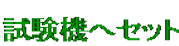
三轴詰㻌桡 $の$ 中て

1.0kPaま?

等方涂荷

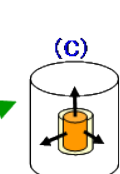

所定 0 拘束圧まて 等方压佫 等方坐䔄 "."." (B)

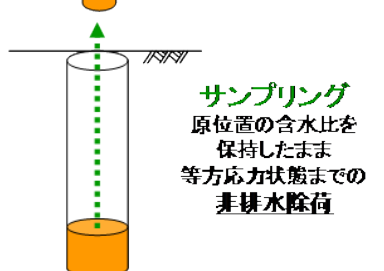

(A)原位置

図 6 計算過程のイメージ図 ${ }^{5}$
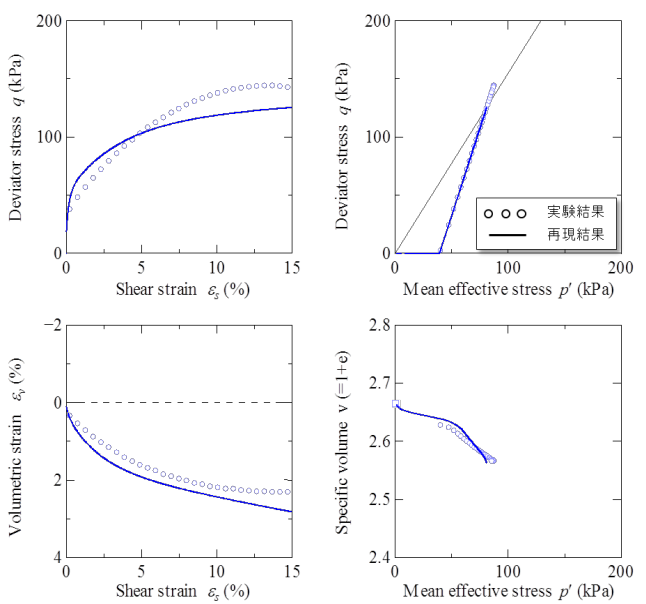

図 7 埋立土の排水せん断挙動とその再現
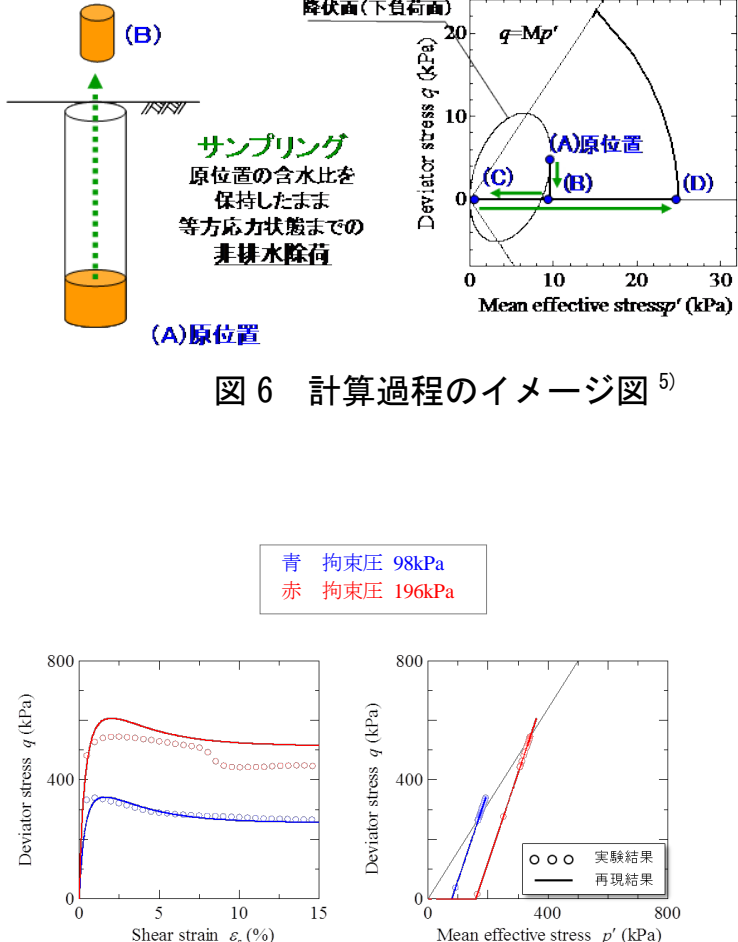

(1)

(D) 圾検阔始時

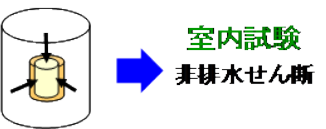

拘束圧 $196 \mathrm{kPa}$
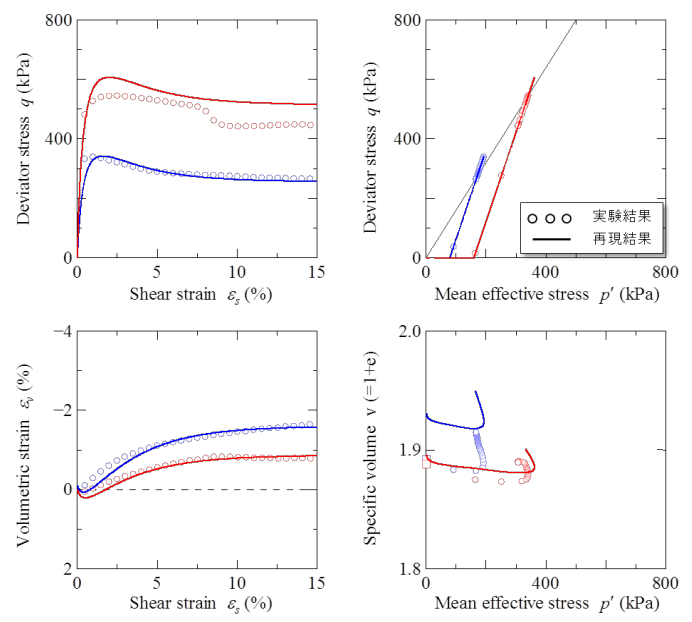

図8 沖積砂の排水せん断挙動とその再現

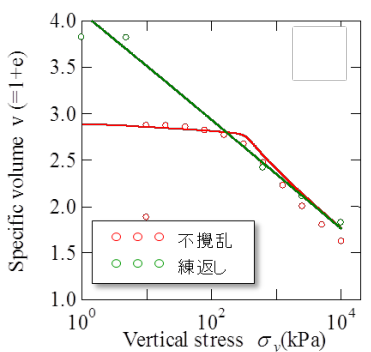

(a) A地点

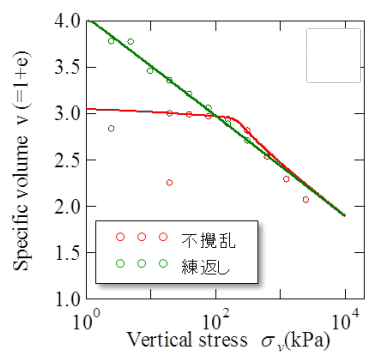

(b) B地点

図10 Ac層上部（Ac1）の圧縮特性の比較

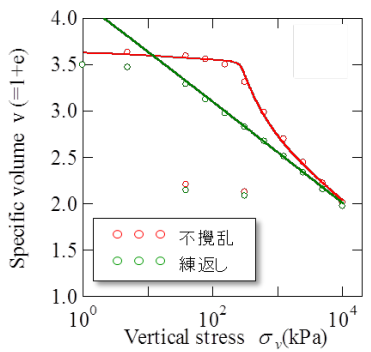

(a) A地点

図11 Ac層中部（Ac2）の圧縮特性の比較 


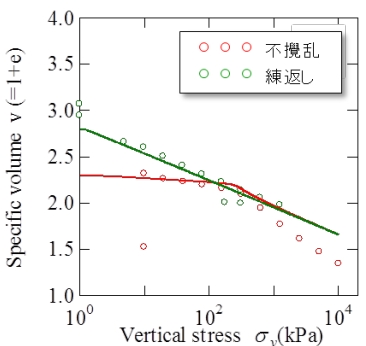

(a) A地点

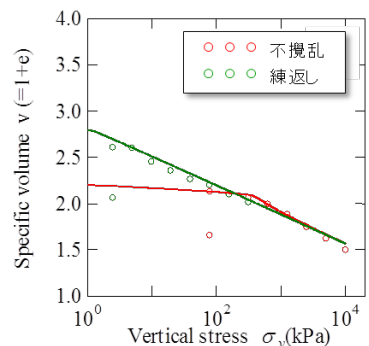

(b) B地点
図12Ａc層下部（Ac3）の圧縮特性の比較

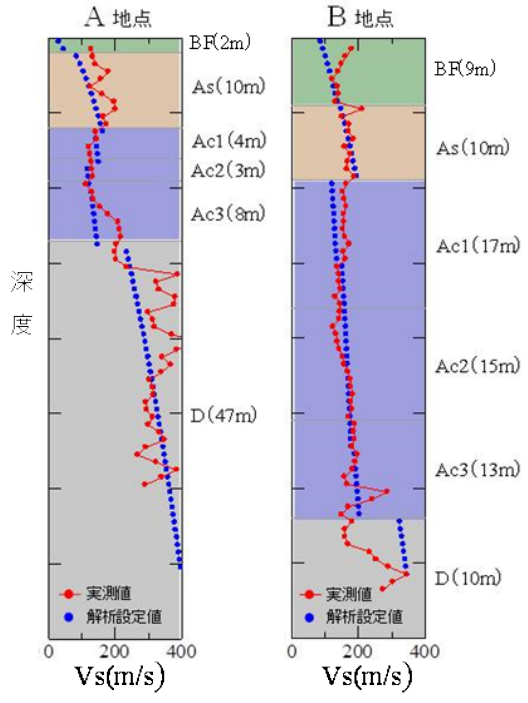

図 $13 \quad A 、 B$ 地点の一次元モデル

表4 材料定数と初期状態

\begin{tabular}{|c|c|c|c|c|c|c|}
\hline ＜弾塑性パラメータ＞ & $\mathrm{BF}$ & As & Ac1 & Ac2 & Ac3 & $\mathrm{D}$ \\
\hline 圧縮指数 $\lambda$ & 0.09 & 0.07 & 0.28 & 0.28 & 0.12 & 0.08 \\
\hline 膨潤指数 $\widetilde{\kappa}$ & 0.01 & 0.002 & 0.02 & 0.02 & 0.01 & 0.001 \\
\hline 限界状態定数 M & 1.40 & 1.43 & 1.40 & 1.40 & 1.40 & 1.50 \\
\hline NCLの切片 $\mathrm{N}$ (at $p^{\prime}=98 \mathrm{kPa}$ ) & 2.45 & 2.01 & 2.82 & 2.82 & 2.00 & 2.05 \\
\hline ポアソン比 v & 0.10 & 0.25 & 0.10 & 0.10 & 0.10 & 0.28 \\
\hline \multicolumn{7}{|l|}{ ＜発展則パラメータ＞ } \\
\hline 正規圧密粘土化指数 $m$ & 8.00 & 8.00 & 20.00 & 20.00 & 20.00 & 0.05 \\
\hline 構造劣化指数 $a(b=c=1)$ & 0.10 & 8.00 & 0.65 & 0.65 & 0.65 & 1.00 \\
\hline $\begin{array}{l}\text { 構造劣化に及ぼす偏差成分の } \\
\text { 割合 } C \mathrm{~s}\end{array}$ & 0.80 & 1.00 & 0.40 & 0.40 & 0.40 & 0.50 \\
\hline 回転硬化指数 $b_{r}$ & 0.50 & 3.00 & 0.20 & 0.20 & 0.20 & 0.20 \\
\hline 回転硬化限界指数 $m_{b}$ & 0.70 & 0.50 & 1.00 & 1.00 & 1.00 & 0.70 \\
\hline \multicolumn{7}{|l|}{ < <初期条件 $>$} \\
\hline 初期異方性 $\zeta_{0}$ & 0.13 & 0.00 & 0.40 & 0.33 & 0.35 & 0.35 \\
\hline 初期応力比 $\eta_{0}$ & 0.55 & 0.55 & 0.55 & 0.55 & 0.55 & 0.55 \\
\hline 構造の程度 $1 / R^{*}$ & 2.79 & 1.20 & 4.55 & 13.30 & 12.13 & 100.00 \\
\hline 初期過圧密比 $1 / R$ & 1.90 & 6.50 & 1.55 & 1.14 & 1.90 & 10000.00 \\
\hline 土粒子密度 $\rho\left(\mathrm{g} / \mathrm{cm}^{3}\right)$ & 2.68 & 2.79 & 2.69 & 2.96 & 2.96 & 2.65 \\
\hline 透水係数 $k(\mathrm{~m} / \mathrm{sec})$ & $1.0 \times 10^{-5}$ & $1.0 \times 10^{-4}$ & $1.0 \times 10^{-7}$ & $1.0 \times 10^{-8}$ & $1.0 \times 10^{-9}$ & $1.0 \times 10^{-6}$ \\
\hline
\end{tabular}

\section{3. 基盤上昇波の推定}

\section{1 解析条件}

本章では、基盤上昇波の推定のための解析条件を示す。対象としたのは、図2中に示すK-NET浦安観 測点である。同地点では、東北地方太平洋沖地震における地表強震記録があるが、深部での観測波は得 られていない。図14にK-NET浦安での地盤情報6を示す。なおここでは原文引用のため埋土・盛土はFl と示す。図15に解析で用いた3次元柱状モデルの境界条件などを示す。K-NET浦安地区の地盤情報では

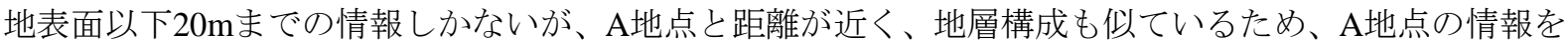
参考に深部をモデル化した。柱状モデルの深度は74mとし、この底面を基盤面と見做して、地震波は底 面(粘性境界 $(\mathrm{Vs}=400 \mathrm{~m} / \mathrm{s}))$ に2 $\mathrm{E}$ 入力した。 


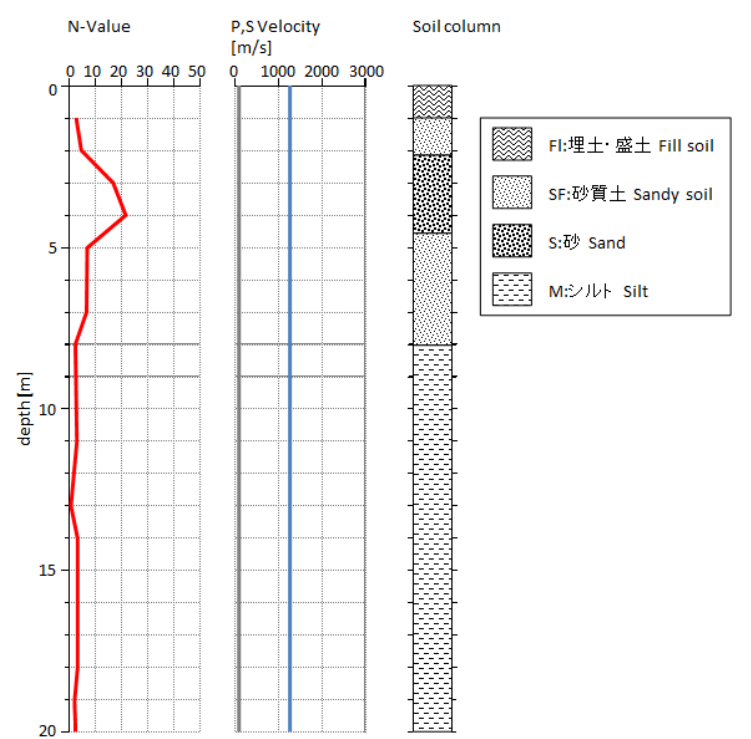

図14Ｋ-NET浦安地点での地盤情報

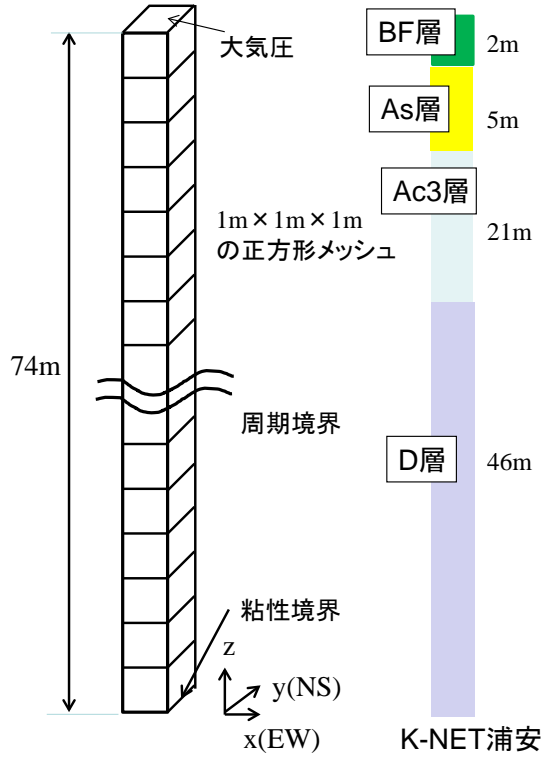

図15 解析モデル

\section{2 基盤上昇波の推定結果}

入力地震波の推定は図16のように行った。まず、K-NET浦安の地表観測波の加速度履歴を $1 / 4$ 倍したも の(i0)を解析モデル（図15）の下端に2E波として、EW、NS両方に同時に入力し（図1611）、地表面観測 波 $(a 0)$ をそれそれの方向で求めた（図16(2)）。これは初期值なのでどのような波を入れてもよいが、簡 易的に観測波の周波数成分を持つものをここでは入力している。求めた地表面観測波 $(a 0)$ と K-NET浦安

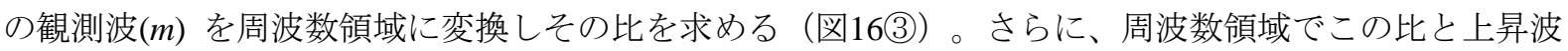
(i0)をかけて次のステップの推定基盤上昇波(i1)を作製する。そしてこの推定基盤上昇波(i1)を時間領域に 変換し、次のステップの時刻歴の推定基盤上昇波を作成する。次式に示す。

$$
i 1=\frac{i 0 \cdot m}{a 0}
$$

なお、推定する場合、特定の周波数帯で解析の地表面波の成分 (a0)が少なく、結果としてその成分で推定基盤上昇波(i1)を大きく 評価する場合があった。このような場合はその成分を削除した。 さらに、何度か繰り返して推定基盤上昇波を作成するが、非線形 解析ではあらゆる周波数帯で完全に一致することは困難なため、 第1および第2スペクトルのピークがほぼ一致するように推定を 行った。また、推定基盤上昇波では0～60秒、および 150 秒以上で 振幅が大きくなっているため、観測波を再現するように振幅を一 律に低減させた。

図17にEW成分、図18にNS成分の地表面観測加速度波(a)、推定 基盤上昇波による地表面応答加速度波(b)、またそれぞれの加速度

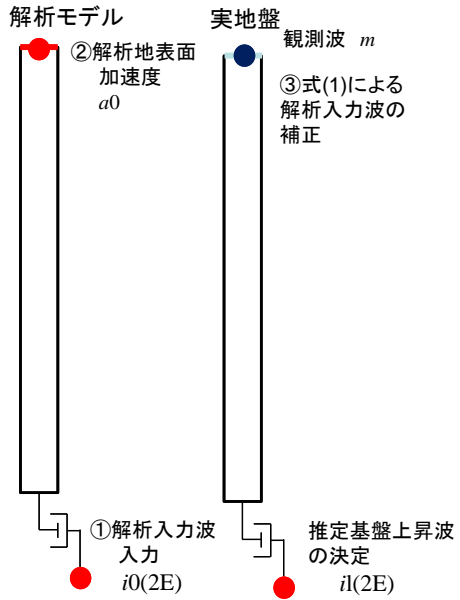

図 16 地震波の推定方法 フーリエスペクトル(c)、(d)および加速度応答スペクトルの比較(e)を示す。時刻歴応答を見ると、EW成 分ではピークが発生する時刻が再現できていないといった若干の差異はあるものの、応答が大きい 100 秒から150秒の区間では観測波をよく再現できている。加速度応答スペクトルでは、EW成分では2Hz以 降のピークが発生する周波数が異なる部分も若干あるが、NS成分ではおおむ観測波を再現できている。 また、加速度応答スペクトルを見ると、第1、2ピーク付近は再現できていると考えられる。図19に基盤 推定上昇波を示す。EW成分では最大加速度 $0.58 \mathrm{~m} / \mathrm{s}^{2} 、 \mathrm{NS}$ 成分では $0.44 \mathrm{~m} / \mathrm{s}^{2}$ となった。 


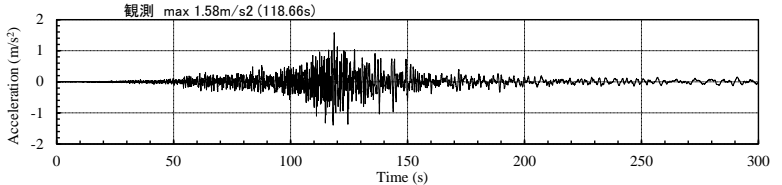

(a) 観測加速度波

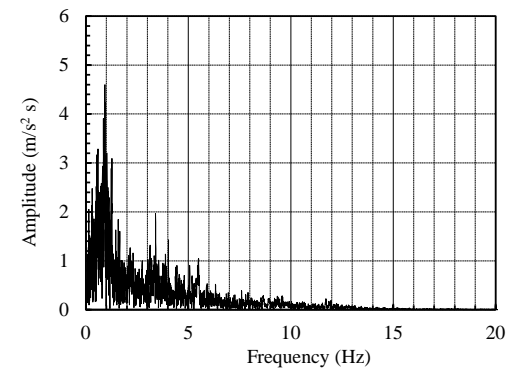

（c）観測波フーリエスペクトル

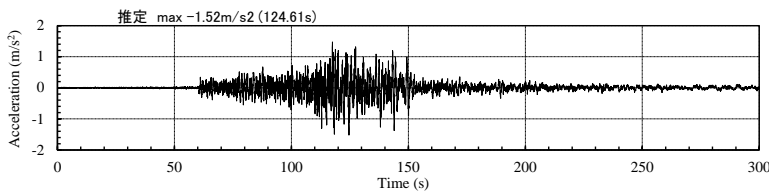

（b）地表推定加速度波

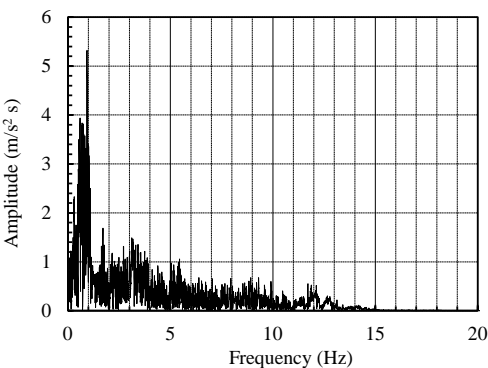

（d）地表推定波フーリエスペクトル

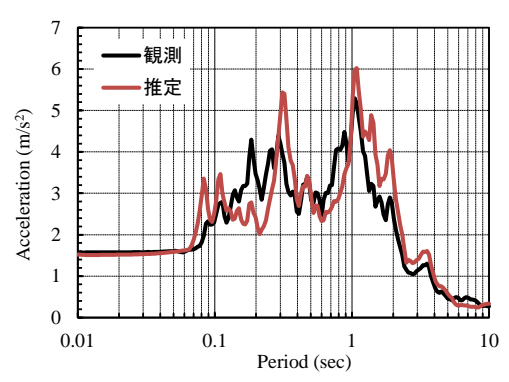

（e）加速度スペクトル比較

図17＼cjkstart観測波と地表推定波の比較（EW成分）

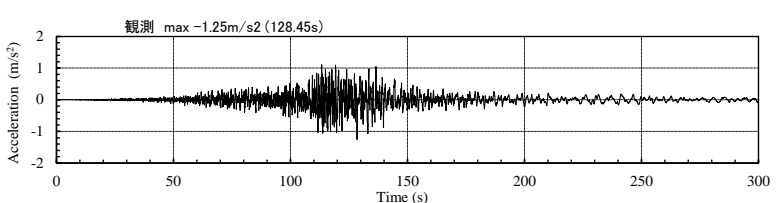

（a）観測加速度波

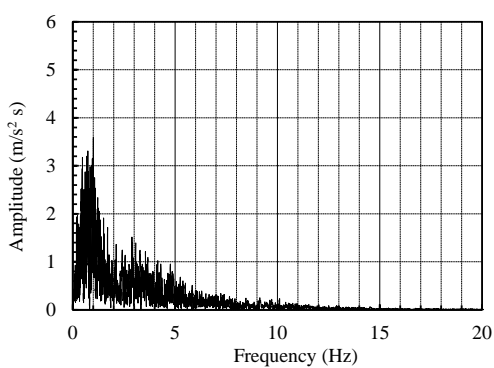

（c）観測波フーリエスペクトル

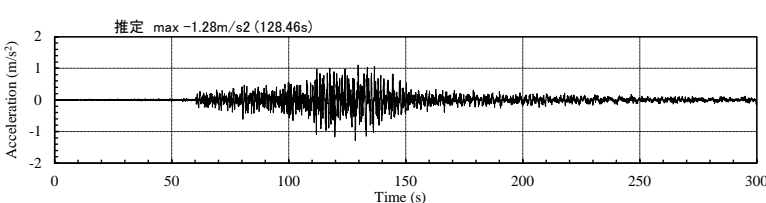

（b）地表推定加速度波
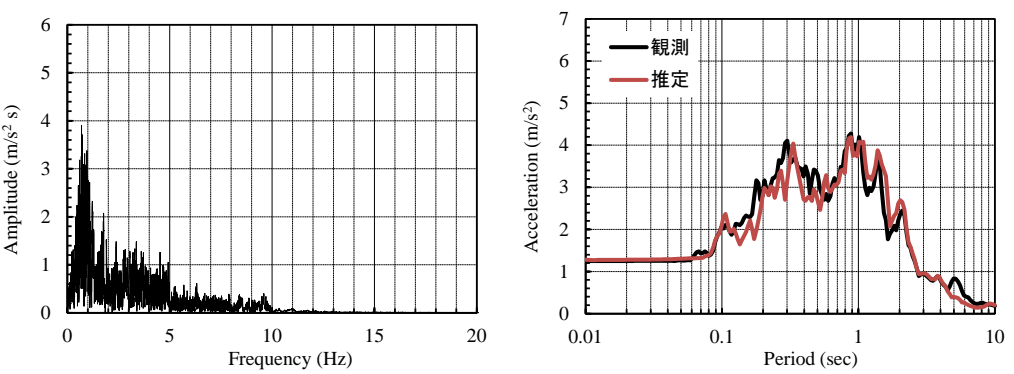

（d）地表推定波フーリエスペクトル（e）加速度スペクトル比較

図18＼cjkstart観測波と地表推定波の比較（NS成分）

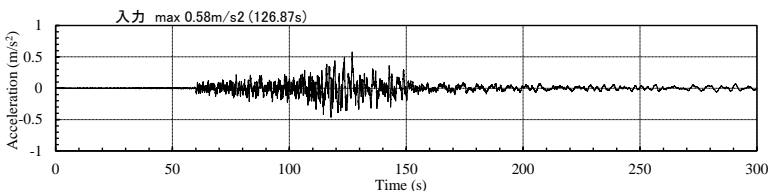

（a）EW波

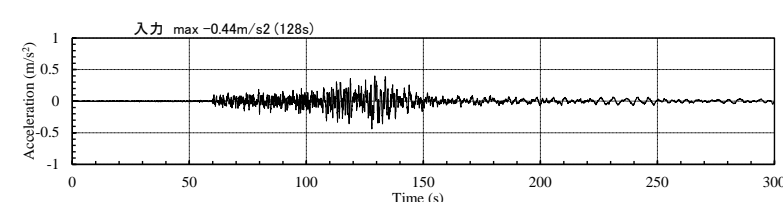

（b） NS波

図19＼cjkstart基盤推定上昇波

次に推定基盤上昇波による各層の挙動について述べる。図20にAcおよびBF層の中心（BF層は2要素の みなのでAc層に近い要素）の要素の平均有効応力低減率の時刻歴を示す。まず地表面に近いBF層で平均 有効応力低減率が増加するが、120秒過ぎの比較的加速度が大きくなっている時刻からAs層が低減して いく。このためBF層には増幅された波が伝わりにくくなりBF層の低減が減少したと考えられる。BF層 は0.90、As層は0.67と液状化に近づいてはいるが、ともに液状化には達していない。このことはK-NET 浦安では液状化が観測されていないことと整合する。図21(a)にEW方向、(b)にNS方向の推定基盤上昇波、 D、Ac、As、 BF層の各層の上端の加速度応答スペクトルを重ねて示す。 EW方向、NS方向ともに、 
洪積D層ではほとんど増幅されていないが、Ac層通過後は1～2秒付近のやや長周期成分で大きく増幅さ れている。沖積砂As層では大きな増幅は見られないが、埋立土BF層では0.3秒付近の短周期成分で増幅 が見られる。図20でBF層で60秒から平均有効応力が急激に低減していくのはこの短周期による増幅によ ってBF層にせん断力が発生したためであると考えられる。

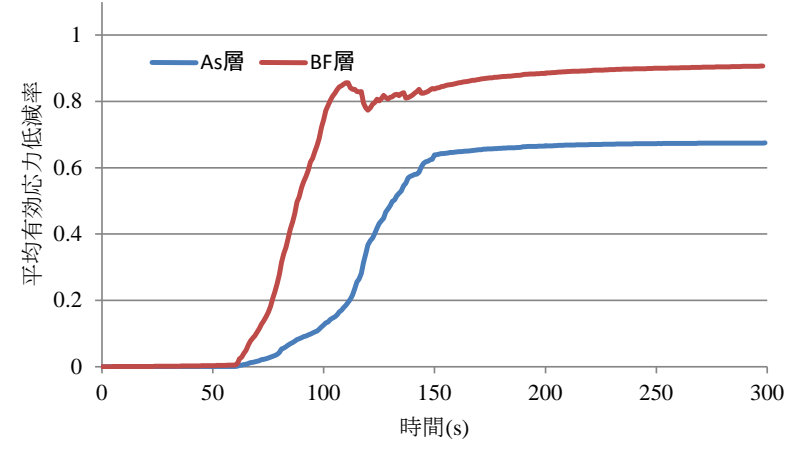

図 20 平均有効応力低減率の時刻歴

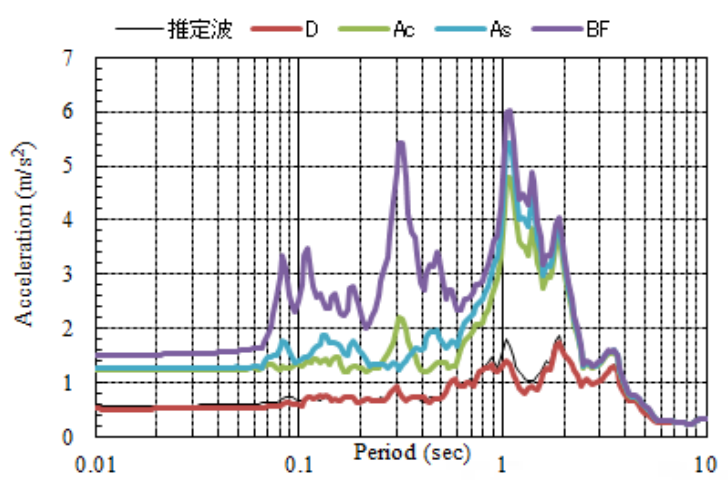

(a) EW 方向

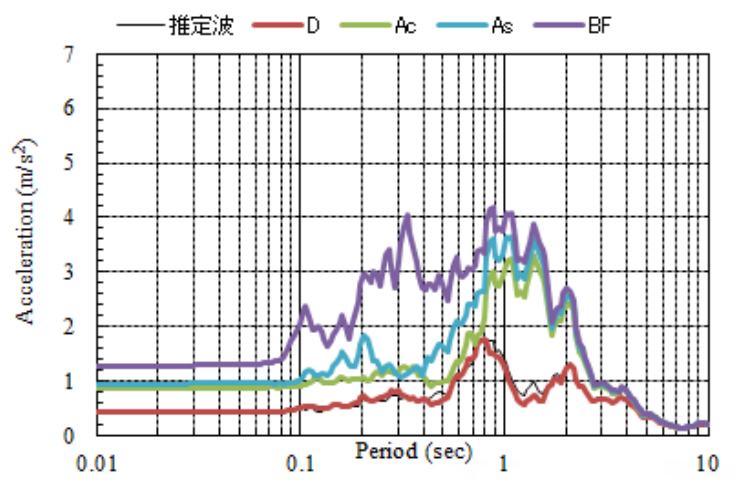

(b) NS 方向

図 21 各層の加速度応答スペクトル

\section{4. おわりに}

本論文では、浦安地区を対象に、正確な地盤材料物性の把握と基盤上昇波の推定を目的とした。本研 究で得られた知見を以下に示す。

1) 浦安地区で2か所ボーリング調査を行った結果、(1)浦安地盤は大別して、表層から埋立土 (BF層)、 沖積砂（As層）、沖積粘土（Ac層）と堆積し、その下に比較的硬質な洪積層（基盤）が堆積してい ること、(2)基盤面は陸側から海側へ向かって深くなっており、沖積粘土層厚は海側へ行くほど厚く なることがわかった。

2) 粘土、中間土、砂まで表現できる弾塑性構成式SYS Cam-clay modelを用いて地盤のパラメータの同 定を行った。サンプリング時の乱れを構成式で表現し、埋立土、沖積砂、沖積粘土の非排水三軸試 験結果の再現を実施した。その結果、(1)埋立土の排水せん断挙動は体積収縮（負のダイレイタンシ 一）が見られ、締まった状態ではなかったこと、(2)沖積砂の排水せん断挙動は体積膨張（正のダイ レイタンシー) が見られ、やや密に締まった状態にあったこと、(3)沖積粘土の非排水せん断挙動は ひずみ軟化挙動を示し、構造高位で鋭敏な状態にあったこと、(4)異なる2地点の力学挙動を比較し た結果、沖積粘土はその状態から3層に分割することができ、相対的に同じ深さにある場合は同じ 状態量にあったことがわかった。

3) 同定した弾塑性パラメータのもと、3次元柱状モデルでK-NET浦安で観測された東日本大震災にお 
けるEW、NSの2方向地震動を同時に再現する基盤上昇波の推定を行った。推定方法は、基盤波と 観測波の伝達関数を用いて、推定波を補正する方法である。加速度時刻歴応答や加速度フーリエス ペクトルはEW成分で一部再現できていない周波数帯があるが、加速度応答スペクトルにおける第1 および第2ピークなど、主要な特徴は再現することができた。

4） K-NET浦安地点における推定基盤上昇波による地震応答解析の結果、Ac層の粘性土地盤で1秒付近 の加速度が大きく増幅され、表層のBF層によって0.3秒付近の加速度が若干増幅されたことがわか った。また、本解析では埋立土と沖積砂の平均有効応力低下率は1.0に近づいたものの液状化にま では達しなかった。液状化しなかったことは実際の観測結果とも一致する。

\section{謝 辞}

本研究は、地盤工学会東日本大震災対応調査研究委員会「地盤変状メカニズム研究委員会（委員長： 浅岡顕)」において検討したものである。また、本論文の作成に当たっては、防災科学技術研究所保有の K-NET浦安の観測波を用いた。また、図2ではGoogle Map を修正・加筆した。記して関係各位に御礼申 し上げる。

\section{参考文献}

1) 国土交通省：液状化対策技術検討会議報告書、2011年.

2) Asaoka, A., Noda, T., Yamada, E., Kaneda, K. and Nakano, M.: An elasto-plastic description of two distinct volume change mechanisms of soils, Soils and Foundations, Vol.42, No.5, 2002, pp.47-57.

3) Noda, T., Asaoka, A. and Nakano, M.: Soil-water coupled finite deformation analysis based on a rate-type equation of motion incorporating the SYS Cam-clay model, Soils and Foundations, Vol.48, No.6, 2008, pp.771-790.

4) 浦安市液状化対策技術検討調查委員会 : 第4回浦安市液状化対策技術検討調查の結果概要について (http://www.city.urayasu.lg.jp/_res/projects/default_project/_page_/001/002/934/00_kekkagaiyou.pdf)、2011 年.

5) Noda, T., Takeuchi, H., Nakai, K. and Asaoka, A.: Co-seismic and post-seismic behavior of an alternately layered sand-clay ground and embankment system accompanied by soil disturbance, Soils and Foundations, Vol.49, No.5, 2009, pp.739-756.

6) 防災科学技術研究所 : http://www.kyoshin.bosai.go.jp/kyoshin/. 


\title{
Investigation of Soil Properties and Estimation of Upward Wave in Foundation Ground of Urayasu Area during the Great East Japan Earthquake using K-NET Record Motions
}

\author{
KANEDA Kazuhiro $^{1)}$, NAKAI Kentaro ${ }^{2)}$, NODA Toshihiro ${ }^{3)}$, \\ ASAOKA Akira ${ }^{4)}$ and SAWADA Yoshihiro ${ }^{5)}$ \\ 1) Chief Researcher, Research and Development Institute of Takenaka Corporation, Dr. Eng. \\ 2) Associate Professor, Nagoya University, Dr. Eng. \\ 3) Professor, Nagoya University, Dr. Eng. \\ 4) Association for the Development of Earthquake Prediction, Dr. Eng. \\ 5) Association for the Development of Earthquake Prediction, Dr. Science
}

\begin{abstract}
The widespread liquefaction disaster that occurred in the reclaimed land around Tokyo bay area during the Great East Japan Earthquake was alarming. Validating this disaster by simulation is needed to prevent any liquefaction that may occur during likely huge future earthquakes. To this end, accurate soil properties and appropriate input wave as well as the finite deformation analysis that simulates the reappearance of liquefaction should be comprehended. In this study, soil-water coupled analysis code GEOASIA with SYS Cam-clay model, which can reproduce the function of soil structure, was used. Firstly, elasto-plastic properties of Urayasu soils were identified from the results of boring survey and laboratory testing. Then, by means of transfer method, both NS and EW upward waves at the foundation ground were simultaneously estimated from K-NET recorded motions at Urayasu.
\end{abstract}

Keywords: Elasto-plasticity, estimation of earthquake wave, seismic response analysis 